\title{
Mechanisms for freezing terrorist assets and their using within the operational-search activity
}

\author{
Maksim Leonidovich Rodichev ${ }^{{ }^{*}}$, Yulia Aleksandrovna Lozina ${ }^{2}$, Anton Dmitrievich \\ Krivobokov $^{3}$, Artyom Aleksandrovich Lobanov ${ }^{3}$, and Maria Valeryevna Rodicheva ${ }^{3}$ \\ ${ }^{1}$ Saint Petersburg University of the Ministry of the Interior of Russia, Department of Operational- \\ Search Activity, Saint Petersburg, Russia \\ ${ }^{2}$ Saint Petersburg University of the Ministry of the Interior of Russia, Department of Citizen Rights \\ and Civil Proceedings, Saint Petersburg, Russia \\ ${ }^{3}$ Saint Petersburg University of the Ministry of the Interior of Russia, Department of Economic \\ Security and Social and Economic Processes Management, Saint Petersburg, Russia
}

\begin{abstract}
One of the areas of focus of counterterrorism efforts is eliminating the financial capabilities of terrorism. It is performed using different mechanisms which include tools of freezing property used for acts of a terrorist nature or their financing. The results of the application of the above-mentioned mechanisms allow making a supposition of the lack of efficacy of their use. As can be seen from the above, a need for scientific studies of problems related to using tools of freezing terrorists' assets arises in order to increase its efficiency. The purpose of this study is to identify problems arising in the field of using tools of freezing property belonging to persons involved in acts of a terrorist nature. The empirical foundation of the study was the information concerning the activity progress in the area of combating the financing of terrorism, as well as the legal instruments that regulate this work. As part of the study, the methods of theoretical modeling, analysis and synthesis of principles of law and legal interpretation were applied. The study performed allowed coming to some results not previously presented in the scientific literature. Thus, the authors drafted proposals of affording a legal opportunity for all authorities authorized to perform operational-search activity, of submitting in a proactive manner at the Rosfinmonitoring (the Federal Financial Monitoring Service of the Russian Federation) the documents containing foundations for the insertion in the List of Individuals and Groups, in respect of which there is information about their involvement in extremist activities or terrorism, as well as of introducing changes in Art. 11 of the Federal Law "Concerning operationalsearch activity", which allow using the results of operational-search activity for making decisions on freezing assets belonging to persons involved in acts of a terrorist nature or its financing.
\end{abstract}

Keywords: terrorism; financing of terrorism; freeze on assets; operationalsearch activity

\footnotetext{
* Corresponding author: petrogradets@bk.ru
} 


\section{Introduction}

The intensity of acts of a terrorist nature directly depends on the level of their financing and material and technical resources. In connection therewith, the destruction of economic basics of terrorist organizations is generally one of the most important fields of anti-terrorism effort.

A significant number of Russian scientists studied the problems of combating the financing of terrorism; among them, one should note the works by Vasnetsova et al. [1], Krasinskii [2], Butkevich [3], Stolyarova et al. [4], Bogomolov [5], Baturina and Litvinenko [6] and Loskutov et al. [7].

Among specialists in operational-search activity, Gusev [8], Chechetin [9], Shakhmatov [10], Ilyin [11], Sharov [12], and Mischenko [13] studied the problems of anti-terrorism effort.

Among foreign researchers, it is worth noting Nimrod Raphaeli [14], Mark Pieth [15], Sidney Weintraub [16], Teichmann [17], and Mekpor [18], whose works on the range of problems under consideration are most often referred to.

\section{Results and discussion}

Freezing assets belonging to persons involved in terrorist activities is one of the most effective tools of the system of destruction of financial basics of terrorist groups.

Currently, the Russian Federation (hereinafter referred to as the RF) has sufficiently broad abilities to deprive terrorists and persons who finance them of assets and tools related to the financing of acts of terrorism.

The following procedures for freezing terrorist assets are applied in the RF:

1. Freeze on assets of the persons included in the List of Individuals and Groups, in respect of which there is information about their involvement in extremist activities or terrorism or in the List of Individuals and Groups in respect of which there is information about their involvement in the proliferation of weapons of mass destruction.

2. Freeze on assets of the persons in virtue of resolutions of the Inter-institutional Commission for Combating the Financing of Terrorism.

3. Blocking financing transactions at the instance of the Federal Financial Monitoring Service of the Russian Federation (Rosfinmonitoring) ("mechanism "5+30").

It should be stated that the first two mechanisms are cumbersome enough.

Thus, the List of Individuals and Groups, in respect of which there is information about their involvement in extremist activities or terrorism (hereinafter referred to as the List) is formed in accordance with paragraph 2.1 of Part 2 of Article 6 of the Federal Law No. 115FZ [19] and includes an international part (sanctions lists of resolutions of the United Nations Security Council 1267/1989/2253 and 1988) and a national one. The order of its creation is implemented in accordance with the RF Government Ordinance dated August 6, 2015 No. 804 [20].

The norms of creation of the List of Individuals and Groups in respect of which there is information about their involvement in the proliferation of weapons of mass destruction and use related to such a list of information are approved by the RF Government Ordinance dated October 26, 2018 No. 1277 [21].

Without a detailed description of the procedure of insertion of persons into the lists and freeze on their assets, it stands to mention a series of problems existing in this field.

First, the mechanism under consideration does not allow freezing promptly the assets belonging to persons involved in terrorist acts, because it takes a fair amount of time to prepare and send documents containing pertinent grounds for the inclusion in the Lists for the consideration of these documents by Rosfinmonitoring (the Federal Financial Monitoring 
Service of the Russian Federation) and bringing the decision adopted to the notice of institutions which perform transactions involving monetary resources or other assets.

Second, the results of operational-search activity are not grounds for the insertion in the lists.

Third, such subdivisions of operational-search activity as the Russian Foreign Intelligence, Federal Penitentiary Service of Russia, Federal Guards Service, customs authorities, as well as the operating unit of the foreign intelligence service of the RF Ministry of Defense, are not among government authorities authorized in a proactive manner to submit documents containing grounds for insertion into the lists at Rosfinmonitoring (the Federal Financial Monitoring Service of the Russian Federation).

As of September 2018, there were 101 entities and 419 individuals in the international part of the List; 8676 individuals and 485 entities were included in the national part of the List. Since the beginning of 2018, approximately 14.5 million rubles have been frozen on 3061 accounts belonging to the persons included in the List [22].

Table 1. National part of the List.

\begin{tabular}{|l|c|c|c|c|c|c|}
\hline & $\mathbf{2 0 1 3}$ & $\mathbf{2 0 1 4}$ & $\mathbf{2 0 1 5}$ & $\mathbf{2 0 1 6}$ & $\mathbf{2 0 1 7}$ & $\begin{array}{c}\mathbf{2 0 1 8} \\
\text { as of } \\
\text { September } \\
\mathbf{2 0 , 2 0 1 8}\end{array}$ \\
\hline $\begin{array}{l}\text { Number of persons } \\
\text { in the national part } \\
\text { of the List at the } \\
\text { end of the year, } \\
\text { among them: }\end{array}$ & 2848 & 3620 & 5084 & 7005 & 8470 & 9161 \\
\hline Individuals & 2796 & 3559 & 5014 & 6922 & 7988 & 8676 \\
\hline - terrorists & 2237 & 2793 & 4051 & 5749 & 6675 & 7250 \\
\hline - extremists & 559 & 766 & 963 & 1173 & 1313 & 1426 \\
\hline Legal entities & 52 & 61 & 70 & 83 & 482 & 485 \\
\hline - terrorist & 19 & 19 & 22 & 25 & 26 & 26 \\
\hline - extremist & 33 & 42 & 48 & 58 & 456 & 459 \\
\hline $\begin{array}{l}\text { Number of frozen } \\
\text { accounts }\end{array}$ & 1659 & 1934 & 3019 & 4865 & 3958 & 3061 \\
\hline $\begin{array}{l}\text { Amount of frozen } \\
\text { assets (rubles) }\end{array}$ & $\begin{array}{c}14 \\
\text { million }\end{array}$ & $\begin{array}{c}25 \\
\text { million }\end{array}$ & $\begin{array}{c}33 \\
\text { million }\end{array}$ & $\begin{array}{c}24 \\
\text { million }\end{array}$ & $\begin{array}{c}15 \\
\text { million }\end{array}$ & $\begin{array}{c}14.5 \\
\text { million }\end{array}$ \\
\hline
\end{tabular}

The mechanism of the List in the RF is amplified by a tool of the prompt freeze on assets - Inter-institutional Commission for Combating the Financing of Terrorism (hereinafter referred to as the Commission).

When necessary, the resolutions of the Commission are adopted within a few days upon receipt of materials from the competent authorities, including foreign countries.

The Commission is composed of the high-ranking functionaries of Rosfinmonitoring (the Federal Financial Monitoring Service of the Russian Federation), Ministry of the Interior, Federal Security Service, and Ministry of Foreign Affairs of the RF; it is headed by the Deputy Director of Rosfinmonitoring.

To adopt a resolution on the freeze, the Commission needs sufficient grounds for suspecting the involvement of a person in acts of a terrorist nature or financing of terrorism.

Therefore, an appeal to the Commission should be based on the set of facts that allow its members to make a conclusion on the degree of the justifiability of the suspicion. The involvement of the object of freeze in the financing of terrorism or acts of a terrorist nature 
should be confirmed not only by financial transactions but also by the facts which indicate that its nature is not accidental, but intentional.

After the Commission adopts a decision, it is immediately brought to the notice of all entities which implement transactions involving monetary resources or other assets. In their turn, these entities on the same day freeze all assets of a relevant person or entity and inform Rosfinmonitoring (the Federal Financial Monitoring Service of the Russian Federation) of all the information concerning the client. Rosfinmonitoring sends this information to the originator of the submission for its use during the operational-search activity.

The statistical data on the work of the Commission - the number of persons whose assets are frozen, the number and amount of frozen assets, etc., are exposed in Table 2. As of September 2018, the Commission adopted resolutions in relation to more than 1.6 thousand persons suspected of being involved in the financing of terrorism (including 5 legal entities). The total amount of frozen assets is equal to more than 10 million rubles [22].

Table 2. Results of the work of the Commission for Combating the Financing of Terrorism.

\begin{tabular}{|l|c|c|c|}
\hline & $\mathbf{2 0 1 6}$ & $\mathbf{2 0 1 7}$ & $\mathbf{2 0 1 8}$ \\
\hline $\begin{array}{l}\text { Number of persons whose assets were frozen } \\
\text { according to the resolutions of the Commission, at } \\
\text { the end of the year, among them: }\end{array}$ & 104 & 582 & 1656 \\
\hline Individuals & 104 & 578 & 1651 \\
\hline Number of frozen accounts & 62 & 450 & 427 \\
\hline Amount of frozen assets on accounts (rub.) & 4.2 million & 5 million & 10 million \\
\hline Amount of frozen electronic assets & 14 & 15 & 6 \\
\hline $\begin{array}{l}\text { Amount of frozen electronic monetary resources } \\
\text { (rubles) }\end{array}$ & 120 & 7 thousand & $\begin{array}{c}1.6 \\
\text { thousand }\end{array}$ \\
\hline Legal entities & 0 & 4 & 5 \\
\hline Number of frozen accounts & 0 & 6 & 6 \\
\hline Amount of frozen assets on accounts (rubles) & 0 & 600 & 600 \\
thousand & thousand \\
\hline
\end{tabular}

It may be stated that in the RF, the mechanisms of the Commission are used when considering requests of foreign countries related to the adoption of freeze measures in accordance with the Resolution of the United Nations Security Council 1373.

The major drawback of the mechanism of the Commission is its inability to promptly freeze the assets of persons involved in acts of a terrorist nature or its financing, because it takes a fair amount of time to prepare and submit relevant documents to the Commission and bring the decision adopted to the notice of institutions which perform transactions involving monetary resources or other assets.

The promptest tool which allows freezing transactions on the account on a day-to-day basis is the third of the mechanisms under consideration - the mechanism for the suspense of financial transactions in virtue of the resolution of Rosfinmonitoring (the Federal Financial Monitoring Service of the Russian Federation) (the so-called mechanism "5+30").

It is applied in virtue of information provided by the enforcement authority, when, for example, there is information available that a determined person will receive some monetary resources or some funds will arrive in the account of a determined card for the purpose of financing terrorism. In this case, Rosfinmonitoring (the Federal Financial Monitoring Service of the Russian Federation) informs promptly the credit institutions.

As specified in paragraph 10 of Article 7 of the Federal Law No. 115-FZ, Rosfinmonitoring (the Federal Financial Monitoring Service of the Russian Federation) is 
entitled to inform institutions that perform transactions involving monetary resources or other assets concerning the fact that a legal entity, either expressly or by implication, is owned or controlled by an institution or individual included into the List, or the individual or the legal entity is acting on behalf of or on the direction of such an institution or an individual. After receiving such information, the relevant institutions suspend operations of such persons (except for the operations related to the receipt of funds) for five working days from the date when the client's order on its execution should be fulfilled.

Hereafter, during these 5 days, Rosfinmonitoring (the Federal Financial Monitoring Service of the Russian Federation) carries out an inspection of the financing transactions detected for its possible involvement in acts of a terrorist nature or their financing.

If the information received by Rosfinmonitoring (the Federal Financial Monitoring Service of the Russian Federation) is recognized by this institution as justified, Rosfinmonitoring issues a resolution on the suspension of operations involving monetary resources or other assets for a period of up to 30 days (Article 8 of the Federal Law No. 115FZ).

During this period, an additional inspection of involvement of transactions suspended in the financing of terrorism is carried out, and if such involvement is confirmed, a decision on a long-term suspension of these and other operations of a suspected person may be adopted in virtue of a resolution of the Commission or unlimited suspense of operations may be applied by the decision of a court.

\section{Conclusion}

As can be seen from the above, the performed analysis of problems of use of mechanisms of freezing the assets of persons involved in terrorism by the operating units allows making the following conclusions and putting the following proposals.

First, it is possible to state that the RF has the necessary tools to freeze the assets of persons involved in acts of a terrorist nature based on international law acts. However, the work on freezing the assets of terrorists is characterized by relatively low indicators, which allow making a conclusion on the need to improve it.

Second, it is necessary to include in the current legislation the norms which afford grounds for a temporary block of transactions with real estate in virtue of resolutions of the Inter-institutional Commission for Combating the Financing of Terrorism.

Third, it is necessary to provide a legal possibility for all authorities authorized to perform operational-search activity to submit in a proactive manner to Rosfinmonitoring (the Federal Financial Monitoring Service of the Russian Federation) any documents containing grounds for insertion in the List of Individuals and Groups, in respect of which there is information about their involvement in extremist activities or terrorism.

Fourth, it is necessary to introduce changes into Article 11 of the Federal Law "Concerning operational-search activity", which allow using the operational-search activity results to make decisions on freezing the assets of persons involved in acts of terrorist nature or its financing.

\section{References}

1. A.S. Vasnetsova, G.O. Vilinskii, E.P. Gorshechnikova, F.M. Kobzarev, M.V. Kroz, V.V. Merkuryev, E.N. Primova, N.A. Ratinova, D.A. Sokolov, O.N. Tisen, M.V. Ulyanov, Borba s terrorizmom: novye vyzovy i ugrozy [Anti-terrorism effort: new challenges and dangers] (Prospekt, Moscow, 2019)

2. V.V. Krasinskii, Modern Law, 4, 88-91 (2016) 
3. S.A. Butkevich, Bulletin of Krasnodar University of the Ministry of Internal Affairs of Russia, 3(33), 30-35 (2016)

4. A.N. Stolyarova, M.V. Rusakovich, A.I. Kolgushin, Bulletin of the Russian Academy of Natural Sciences, 16(4), 36-39 (2016)

5. S.Yu. Bogomolov, Otvetstvennost za finansirovanie terrorizma (ugolovno-pravovoe i kriminologicheskoe issledovanie) [Liability for terrorism financing (criminal law and criminological research)], Abstract of a PhD thesis (Nizhny Novgorod Academy of the Ministry of Interior of Russia, Nizhny Novgorod, 2017)

6. E.V. Baturina, A.N. Litvinenko, Legal Science and Practice: Journal of Nizhny Novgorod Academy of the Ministry of Internal Affairs of Russia, 1(45), 84-89 (2019)

7. I.N. Loskutov, M.L. Rodichev, M.V. Semenov, A.V. Shakhmatov, Organizatsiya i taktika protivodeistviya legalizatsii (otmyvaniyu) prestupnykh dokhodov. Uchebnoe posobie [Organization and tactics for combating legalization (laundering) of criminal income. Study guide] (Saint Petersburg University of the Ministry of Internal Affairs of the Russian Federation, Saint Petersburg, 2019)

8. V.A. Gusev, V.F. Lugovik, Teoriya operativno-rozysknykh protsedur [Theory of operational-search procedures] (Prospekt, Moscow, 2019)

9. A.E. Chechetin, Proceedings of Management Academy of the Ministry of the Interior of Russia, 3(55), 65-76 (2020)

10. A.V. Shakhmatov, M.L. Rodichev, Legal Science: History and the Presence, 11, 106117 (2015)

11. E.A. Vasilyev, I.V. Ilyin, A.E. Ilyin, Vestnik of Lobachevsky University of Nizhni Novgorod, 3, 124-130 (2015)

12. V.I. Sharov, Prestupleniya v Internete [Cybercrimes], in Yu.V. Zhuravleva (ed.), Gosudarstvo i pravo v izmenyayushchemsya mire: novye vektory sudebnoi reformy. Materialy III nauchno-prakticheskoi konferentsii s mezhdunarodnym uchastiem [State and law in a changing world: new vectors of judicial reform. Materials of the III scientific-practical conference with international participation], 387-393 (Avtor, Nizhny Novgorod, 2018)

13. L.V. Mischenko, Predmet, zadachi i osnovnye napravleniya prokurorskogo nadzora za soblyudeniem prav i svobod cheloveka i grazhdanina [Subject, tasks and main directions of prosecutor's supervision over the observance of rights and human and civil liberties], in Sotsialno-ekonomicheskie nauki i yurisprudentsiya: teoriya, metodologiya, praktika. Sbornik statei Vserossiiskoi nauchno-prakticheskoi konferentsii prepodavatelei, uchenykh, spetsialistov [Social and economic sciences and jurisprudence: theory, methodology, practice. Collection of articles of the Russian National-wide Research-to-Practice Conference of teachers, scientists and specialists], 152-160 (Nizhny Novgorod State University of Architecture and Civil Engineering, Nizhny Novgorod, 2016)

14. N. Raphaeli. Terror. Political Violence 15(4), 59-82 (2003). https://doi.org/10.1080/09546550390449881

15. M. Pieth. J. Int. Crim. Justice 4(5), 1074-1086 (2006). https://doi.org/10.1093/jicj/mq1062

16. S. Weintraub, Wash. Q. 25(1), 53-60 (2002). https://doi.org/10.1162/016366002753358311

17. F.M.J. Teichmann, J. Money Laund. Control 22(2), 188-194 (2019). https://doi.org/10.1108/JMLC-07-2017-0026 
18. E.S. Mekpor, J. Money Laund. Control 22(3), 451-471 (2019). https://doi.org/10.1108/JMLC-09-2018-0057

19. Federalnyi zakon ot 07.08.2001 No. 115-FZ (red. ot 20.07.2020) “O protivodeistvii legalizatsii (otmyvaniyu) dokhodov, poluchennykh prestupnym putem, i finansirovaniyu terrorizma" [Federal Law No. 115-FZ (version dated July 20, 2020) "Concerning combating legalization (laundering) of criminal income and terrorism financing"] (2001, August 7)

20. Postanovlenie Pravitelstva RF ot 06.08.2015 No. 804 (red. ot 15.10.2020) “ $\mathrm{Ob}$ utverzhdenii Pravil opredeleniya perechnya organizatsii i fizicheskikh lits, v otnoshenii kotorykh imeyutsya svedeniya ob ikh prichastnosti k ekstremistskoi deyatelnosti ili terrorizmu, i dovedeniya etogo perechnya do svedeniya organizatsii, osushchestvlyayushchikh operatsii s denezhnymi sredstvami ili inym imushchestvom, drugikh yuridicheskikh lits, a takzhe fizicheskikh lits" [RF Government Ordinance dated No. 804 (version dated October 15, 2020) "Concerning approval of the Rules of determination of the List of Individuals and Groups, in respect of which there is information about their involvement in extremist activities or terrorism, and bringing the information on the list to the notice of institutions which perform transactions involving monetary resources or other assets, other legal entities, as well as individuals"] (2015, August 6)

21. Postanovlenie Pravitelstva RF ot 26.10.2018 No. 1277 (red. ot 15.10.2020) “Ob utverzhdenii Pravil formirovaniya perechnya organizatsii i fizicheskikh lits, $v$ otnoshenii kotorykh imeyutsya svedeniya ob ikh prichastnosti $\mathrm{k}$ rasprostraneniyu oruzhiya massovogo unichtozheniya, i ispolzovaniya svyazannoi s takim perechnem informatsii" [RF Government Ordinance dated No. 1277 (version dated October 15, 2020) "Concerning approval of the Rules of determination of the List of Individuals and Groups in respect of which there is information about their involvement in proliferation of weapons of mass destruction and use of information related to this list"] (2018, October 26)

22. Reference information of Rosfinmonitoring (the Federal Financial Monitoring Service of the Russian Federation). Received by the authors' in person. 